\title{
Procedure to estimate maximum ground acceleration from macroseismic intensity rating: application to the Lima, Perú data from the October-3-1974-8.1-Mw earthquake
}

\author{
L. Ocola \\ Instituto Geofísico del Perú, Sector Educación, Calle Badajoz 169, Lima 3, Perú \\ Received: 15 July 2007 - Revised: 18 October 2007 - Accepted: 18 October 2007 - Published: 2 January 2008
}

\begin{abstract}
Post-disaster reconstruction management of urban areas requires timely information on the ground response microzonation to strong levels of ground shaking to minimize the rebuilt-environment vulnerability to future earthquakes. In this paper, a procedure is proposed to quantitatively estimate the severity of ground response in terms of peak ground acceleration, that is computed from macroseismic rating data, soil properties (acoustic impedance) and predominant frequency of shear waves at a site. The basic mathematical relationships are derived from properties of wave propagation in a homogeneous and isotropic media. We define a Macroseismic Intensity Scale $I_{M S}$ as the logarithm of the quantity of seismic energy that flows through a unit area normal to the direction of wave propagation in unit time. The derived constants that relate the $I_{M S}$ scale and peak acceleration agree well with coefficients derived from a linear regression between MSK macroseismic rating and peak ground acceleration for historical earthquakes recorded at a strong motion station, at IGP's former headquarters, since 1954. The procedure was applied to 3-October-1974 Lima macroseismic intensity data at places where there was geotechnical data and predominant ground frequency information. The observed and computed peak acceleration values, at nearby sites, agree well.
\end{abstract}

\section{Introduction}

Seismic ground acceleration (force per unit of mass) plays an important role in assessing effects of earthquakes on the built environment, persons, and the natural environment. It is a basic parameter of seismic wave motion on which earthquakeresistant building design and construction are based. The level of damage is, among other factors, directly proportional

Correspondence to: L. Ocola

(geo_gps@geo.igp.gob.pe) to the severity of the ground acceleration, and it is important information for disaster-risk prevention and mitigation programs.

Knowledge of the spatial distribution of maximum seismic acceleration in an urban area, due to strong-earthquake shaking, is important for territorial planning and use, urban development, risk management, implementation of disaster prevention measures, community emergency preparedness and other applications. This knowledge is developed through seismic microzoning of urban areas for reliable strong motion estimation, either through comprehensive geophysicalgeotechnical surveys and appropriate numerical modeling, or from having as many seismic strong-motion instruments as possible recording a strong and destructive earthquake. In both cases, significant financing and a long time waiting for an event to occur are required.

However, if a destructive earthquake strikes an urban area, an approximate ground response can be attained through systematic observations of macroseismic effects and a careful ground shaking severity rating, when no such strong motion seismic network exists. In this paper, we report this kind of experiment and the use of macroseismic, geotechnical and predominant frequency data to quantitatively estimate maximum ground acceleration.

Perú's seismicity comprises seismic activity associated with the collision and subduction of the Nazca plate against and under the western border of South America plate, with the continental crustal readjustment due to the collision of these tectonic plates, and with volcanic activity. Large magnitude earthquakes are associated with the collision of these plates. However, the most severe ground shaking is produced by the near surface continental earthquakes associated with geological faults in the upper plate. Figure 2 shows the most dangerous seismicity: Shallow seismicity (depth range: $0-32 \mathrm{~km}$ ). The association of neotectonic faults, the oceanic trench and seismicity is evident. The 3 October 1974, magnitude magnitude $8.1(\mathrm{Mw})$ earthquake occurred

Published by Copernicus Publications on behalf of the European Geosciences Union. 


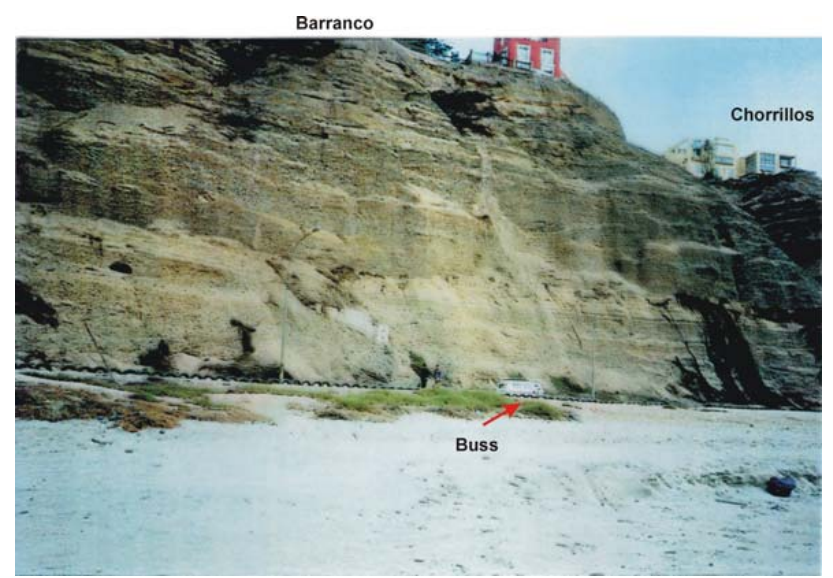

Fig. 1. Rimac delta base stratigraphy along Barranco-Chorrillos districts cliff (Figs. 3 and 4, where " 28 " is sited): Beds and lenses of conglomerate, sand and clay alluvial sediments. The buss at the bottom of the cliff serves as a scale. This photo is near the site where Espinosa et al. (1977) estimated $0.7 \mathrm{~g}$ ground acceleration at the crown.

in the collision environment offshore from Lima, Perú. Data from this event is used in this paper.

\section{The 3 October 1974 earthquake and data acquisition}

The 3 October 1974, earthquake severely shook Lima and Callao (City of Lima) in the central coast of Perú (Fig. 2). It was an 8.1-Mw magnitude subduction earthquake (Fig. 2). The event was located at Lat. $12.24^{\circ} \mathrm{S}$, Lon. $77.58^{\circ} \mathrm{W}$ and at a depth of $27 \mathrm{~km}$ (International Seismological Center), at an epicentral distance of 80-90 km from Lima. The earthquake caused a small- to moderate-sized tsunami, generating waves of $1.52 \mathrm{~m}$ at the La Punta (Callao) tide gauge, and $1.22 \mathrm{~m}$ at the San Juan tide gauge $(410 \mathrm{~km}$ SE of Lima). The earthquake produced extensive ground vertical cracks, and liquefaction in Quilmaná-San Vicente de Cañete, and minor landslides in the Lima city area's coastal cliffs (Espinosa et al., 1977; Giesecke et al., 1980). The relative position of Lima city, the epicenter of the main earthquake and aftershocks are shown in the inset of Fig. 2.

Soon after the 1974 earthquake, the Instituto Geofísico del Perú (IGP), with the assistance of a scientific mission of the United States Geological Survey (USGS), organized a systematic survey of the effects of this earthquake on the popular-built environment. Personnel from IGP under Dr. E. Silgado's supervision interpreted the field data. A total of $\sim 500$ data points were analyzed. The shaking intensities of this earthquake in Lima ranged between Modified Mercalli (MMI) $4^{+}$and 9 . Preliminary results were published by Giesecke et al. (1980). USGS results were published in 1977 (Espinosa et al., 1977, and Husid et al., 1977). The macroseismic map published by Espinosa et al. essentially mirrors the damage pattern map of Husid et al. On the other hand, the spatial distribution of IGP macroseismic intensity, Fig. 3, does not follow the Espinosa et al. (1977) intensity rating pattern. Espinosa et al. (1977) would not had taken into account the vulnerability of the built environment in the assessment of the ground shaking severity.

IGP network recorded this event in two strong-motion stations: One record was obtained at IGP's former headquarters, Lima District (Cod. 9, Figs. 3 and 4) (IGP station) with a Montana Strong Motion instrument, and the other one at Las Gardenias- Santiago-de-Surco District (Cod. 26) (LasGardenias station) with a SMA-1 instrument. According to Moran et al. (1975), the maximum peak ground acceleration at the IGP station was $0.24 \mathrm{~g}$, on the longitudinal component, and $0.18 \mathrm{~g}$ in the transverse component at the Las-Gardenias station. The main features of the strong ground motion were long duration of strong ground shaking $(\sim 100 \mathrm{~s}$ with ground acceleration $>0.01 \mathrm{~g}$ ) and high energy in the high frequency band. At IGP's office in the Magdalena district (Cod 20, Figs. 3 and 4), people reported seeing waves on the ground in a park in front of the office, where they were evacuated at the time of the earthquake.

\section{Relationship between macroseismic intensity and es- timated maximum seismic ground acceleration}

Lima's population density is increasing at a very high rate: The population is more than eight million at present. The number of high-rise buildings in the old and traditional districts of Lima is multiplying very rapidly, and there is not a clear idea on what the overall strong motion ground response would be in metropolitan Lima if an earthquake like the 1974 event were to strike again. The 1974 earthquake is the closest earthquake greater than magnitude $8 \mathrm{Mw}$ that Lima has had in recent times. A seismic hazard assessment of Lima shows that there is a seismic gap between Cañete and Nazca that might be activated in the near future. This gap corresponds to the 1687's (8.4-8.8 Ms magnitude) earthquake rupture area (Langer and Spence, 1995). The length of the gap is similar to the 1974-earthquake-rupture length. Thus, it is proper to assume that the ground shaking in Lima might be similar to that produced by the 3 October, 1974 earthquake, if this gap is activated by a similar large earthquake. An estimate of strong motion response in the Lima Valley (i.e., districts of old Lima) would help to implement mitigation and preventive measures and save many lives and much property. Efforts have been made to outline a vulnerability zoning of the metropolitan districts of Lima based on geotechnical information of the ground and regional seismichazard-probabilistic assessment (CISMID, 2005).

As it was mentioned above, we have strong-motion macroseismic data rating at more than 500 sites in the traditional Lima districts (Fig. 3) from the 3 October 1974, earthquake, and a functional relationship between maximum peak ground 


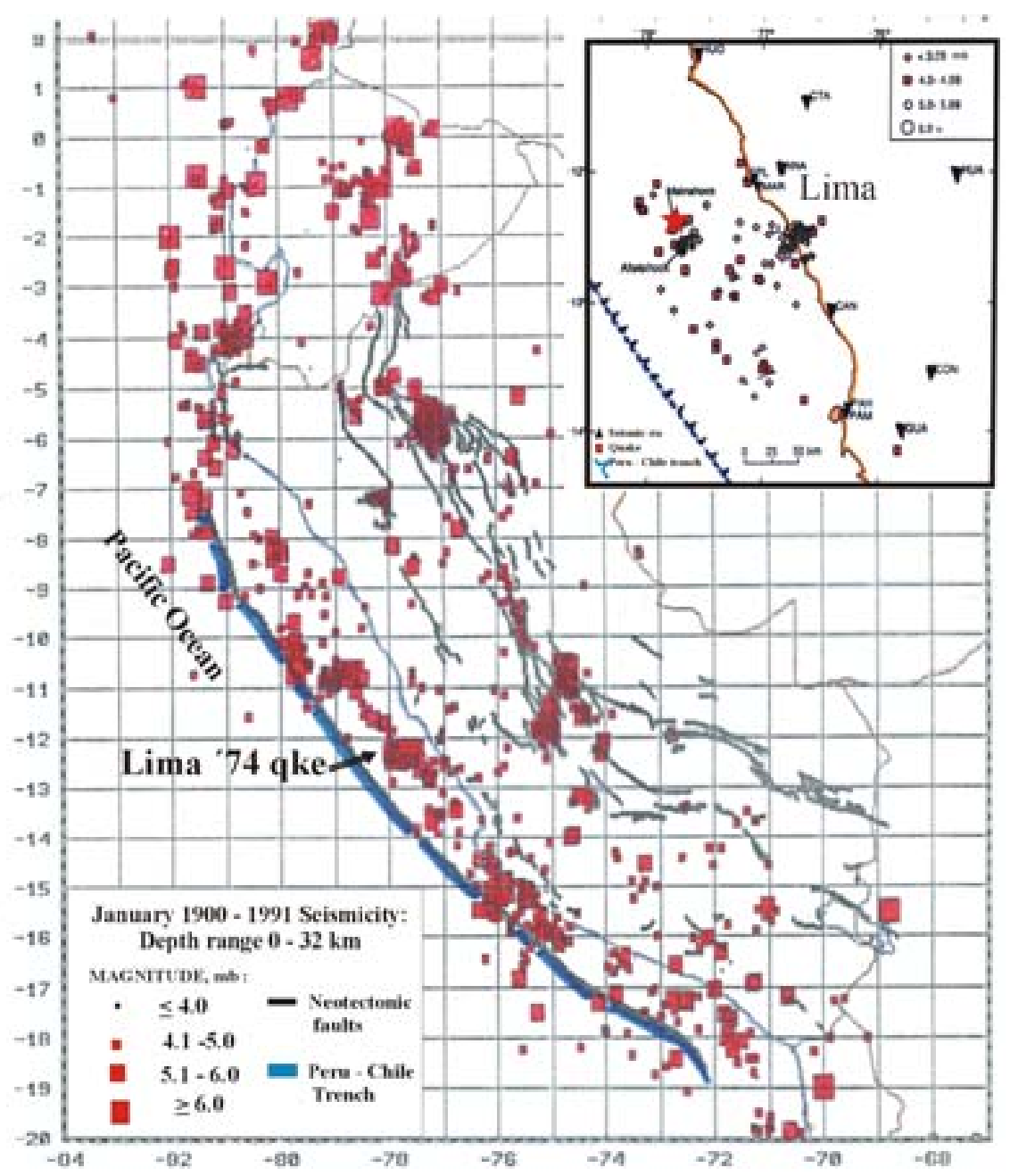

Fig. 2. 1. Peru's shallow seismicity. The insert shows: Location of the 8.1-Mw earthquake epicenter, main aftershock epicenter - 11 November 1974, aftershocks located by the local seismic network, and local seimic stations (inverted triangles), Langer and Spence (1995).

acceleration (PGA) and macroseismic-intensity rating proposed by Ocola (2005). In this paper, progress made for estimating PGA and its comparison with the PGA recorded at IGP strong motion stations during the 3 October 1974 earthquake is reported.

Ocola (2005) considered a simple case of harmonic waves propagating through an homogeneous and isotropic medium (depending on the space coordinates and time). This harmonic wave has a constant amplitude sinusoid displacement, whom velocity and acceleration wave motions are derived.

I.e.: if $u(t, \omega)$ is the displacement for a given place, where $\omega$ : frequency, $t$ : time;

$u^{\prime}=i \omega u(t, \omega), i=(-1)^{\frac{1}{2}}$, is the vibration velocity, and

$u^{\prime \prime}=-\omega^{2} u(t, \omega)$ is the vibration acceleration.

The maximum kinematic parameter values are:

Displacement: $\left.u\right|_{\max }=A$ (constant),
Velocity: $\left.u^{\prime}\right|_{\max }=\left.\omega u\right|_{\max }$,

Acceleration: $\left.u^{\prime \prime}\right|_{\max }=\left.\omega^{2} u\right|_{\max }$.

The intensity $(I)$ of a wave is, usually, defined as the quantity of energy $(K)$ which flows through a unit area $(A)$ normal to the direction of wave propagation in unit time $(t)$ (Telford et al., 1976); i.e.,

$I=K /(A t)$.

where, $K=\frac{1}{2} \rho V u^{\prime 2}, V$ is the volume that contains the energy $K$ at the time $t, \rho$ is the mass density of the medium; or in terms of vibration acceleration:

$K=\frac{1}{2}\left(\rho V / \omega^{2}\right)\left(u^{\prime \prime}\right)^{2}$.

If a cylindrical volume of length $L$ and cross sectional area $A$, and a wave traveling along $L$ with a velocity $v$, are con- 


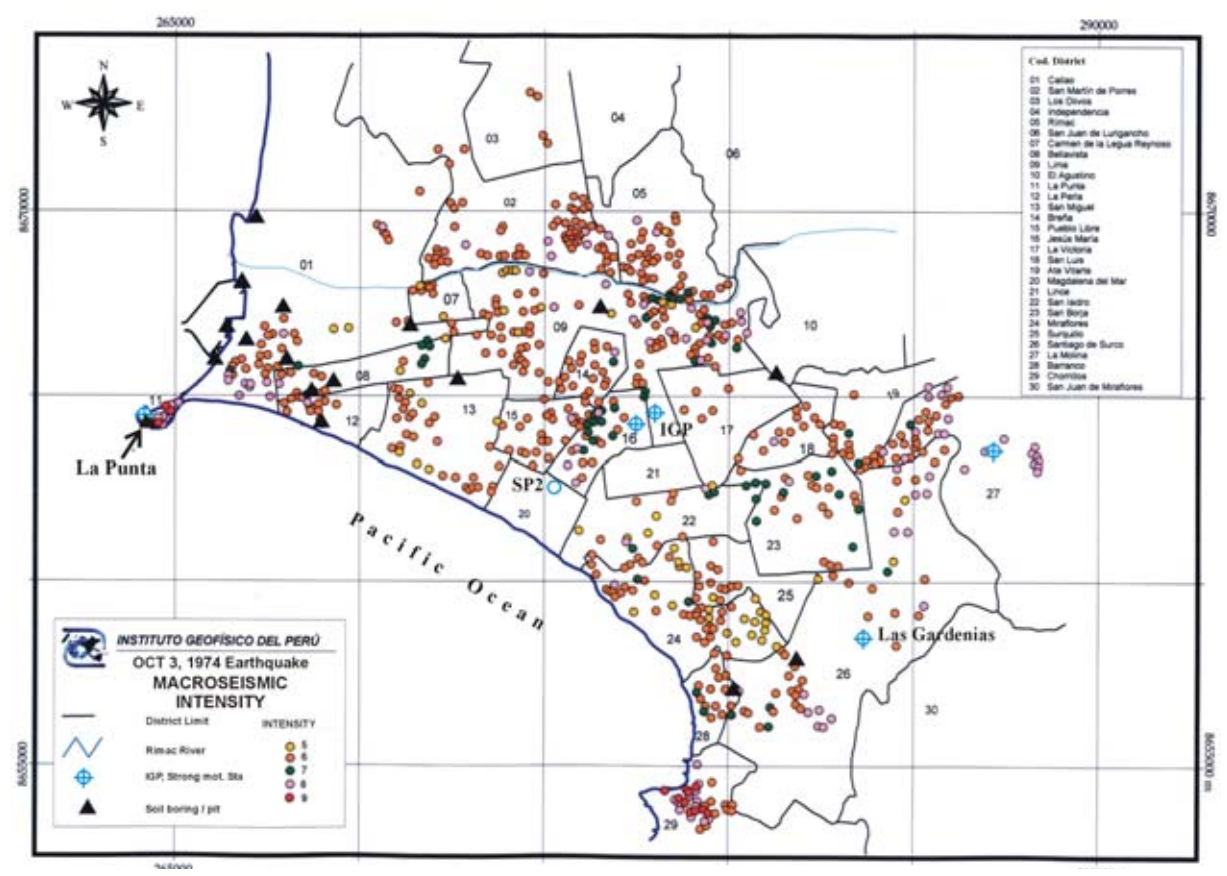

Fig. 3. Color coded of October-3-1974 earthquake macroseismic data (circles) in MSK scale values. Black triangles are boreholes or pits used for geotechnical information. The thin-black lines are district limits, and the small-black numbers are the district codes used in the upper right table: Name of the districs. Open circles (blue) represent IGP facilities or strong motion stations.

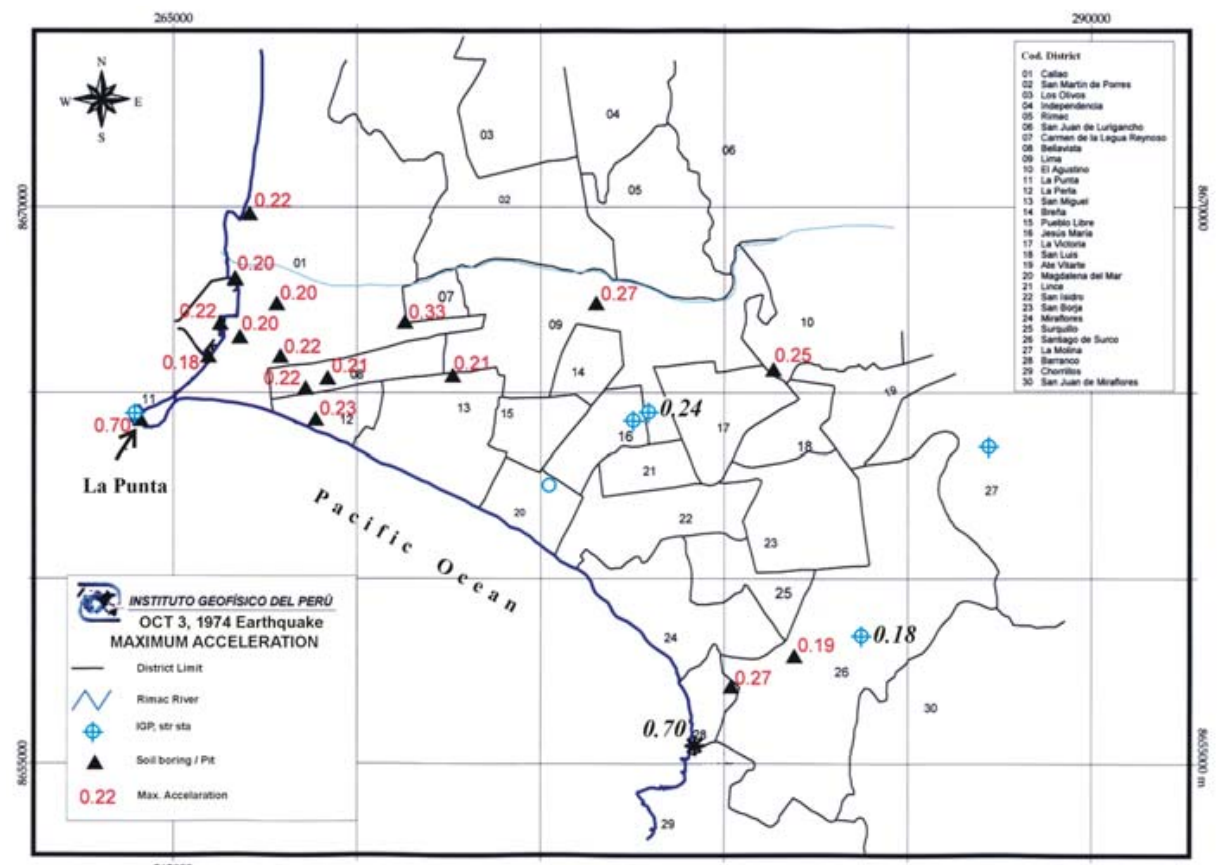

Fig. 4. Maximum seismic acceleration computed at the boreholes/pits with the proposed functional relationship between macroseismic intensity and ground acceleration, in units of " $\mathrm{g}$ " (Earth's gravity acceleration). The $0.7 \mathrm{~g}$ maximum acceleration at La Punta is a computed value, and the $0.7 \mathrm{~g}$ at Barranco is Espinosa et al. (1977) estimated value. Note the relative agreement between the observed values at IGP-Station and Las-Gardenias-Station with the values of the nearby borehole computed numbers. 
sidered, the intensity of the wave is given by:

$I=\frac{1}{2}\left(\rho v / \omega^{2}\right)\left(u^{\prime \prime}\right)^{2}$,

Hence, the wave intensity is a function of the physical properties of the media and wave frequency.

Human perception of different class of natural phenomena, e.g., stars luminosity, sound waves, wind velocity of hurricanes, etc., varies in logarithmic scale. The Macroseismic Intensity Scale $I_{M S}$ is defined by Ocola (2005) as the logarithm of the quantity of seismic energy that flows through a unit area normal to the direction of wave propagation in unit time, i.e.:

$I_{M S}(y)=\log (I(y))$,

where $y=$ vibration acceleration or velocity or displacement.

The macroseismic intensity scale $\left(I_{M S}\right)$ as a function of seismic vibration acceleration is given by:

$I\left(u^{\prime \prime}\right)=\frac{1}{2}\left(\zeta / \omega^{2}\right)\left(u^{\prime \prime}\right)^{2}$, where $\zeta=\rho$ v. If $A=u^{\prime \prime}$,

Then $I_{M S}(A)=\log \left[\frac{1}{2}\left(\zeta / \omega^{2}\right)\right]+2 \log A$.

If $C=\log \left[\frac{1}{2}\left(\zeta / \omega^{2}\right)\right]$

then: $I_{M S}(A)=C+2 \log A$.

The variable $C$ depends on the mechanical properties of the media ( $\zeta$ : acoustic impedance), and the frequency of the seismic waves at the observation site (Ocola, 2005). Therefore, if the maximum seismic acceleration, PGA, at a given site is known, the macroseismic intensity can be estimated. Likewise, if the macroseismic intensity is known, the PGA can be calculated. In this paper, the second alternative is used.

IGP has earthquake strong motion records at the IGP station since 1954. A linear regression between the horizontal PGA plotted in natural logarithm scale and MSK macroseismic intensity rating in neighborhoods of IGP station gives the following parameters for the fitted line: Intercept $=2.30$, slope $=1.99$, Correlation coefficient $=0.96$, variance $=0.05$; i.e., the line equation is

$I(\mathrm{MSK})=2.30+1.99 \log (A o)$,

where Ao is the peak observed seismic acceleration (Ocola, 1981, unpublished).

The IGP station is located on a delta alluvial conglomerate. The estimated shear wave propagation velocity is $\sim 500 \mathrm{~m} / \mathrm{s}$, and the mass density is $\sim 2.0 \mathrm{~g} / \mathrm{cm}^{3}$. The frequency range of the strong motion records is about $2<f<10 \mathrm{~Hz}$, and the predominant frequency of response spectra for 3 October 1974 earthquake is $2.6 \mathrm{~Hz}$ (Espinosa et al., 1977). The equation for the defined macroseismic intensity is $I_{M S}(A)=C+2 \log A$, whose variables $C$ and $A$ were defined above. Based on geotechnical information for IGP station site, values of $C$ for three frequencies were calculated: 1.10 for $f=10 \mathrm{~Hz}, 2.50$ for $f=2 \mathrm{~Hz}$, and 2.3 for $f=2.6 \mathrm{~Hz}$. Hence, there is an agreement between the values of the intercept point in MSK scale regression line and the variable $C$ in $I_{M S}$ at $2.6 \mathrm{~Hz}$ (predominant frequency during the 3 October 1974 earthquake). There is a good agreement between slope values of MSK (1.99) and of $I_{M S}$ (2.0). Thus, the MSK scale and the $I_{M S}$ can be reasonably assumed as equivalents. Therefore, if the geotechnical properties, the propagation velocity, the predominant frequency of the seismic waves, and the macroseismic intensity at any given site are known, the PGA acceleration can be calculated at that site.

\section{Lima geotechnical characteristics}

The city of Lima is located on the Quaternary alluvial cones of the Rimac, Lurin and Chillón rivers. Deposits of Chillón River predominate at north part of La Punta (Callao). The base of its cone does not show any erosional sea cliff. However, the delta base of Rimac river presents cliffs from few meters altitudes in La Perla. (SE of La Punta), to about $70 \mathrm{~m}$ asl in Miraflores (Macazana, 2006). This cliff shows a major depression between Miraflores and Barranco districts, which is an ancient bed of the Rimac River.

The stratigraphy of the Rimac delta is highly variable and lenticular, with beds of cobbles and pebbles and sandy matrix, in the upper part of the cone, and fine sandy beds with lenticular silt and clay deposits, in the lower part, in Callao coastal side districts; e.g., La Punta, Bellavista, etc. The water table is around $400 \mathrm{~m}$ depth in the upper part of the delta and very shallow in Callao districts. The stratigraphic features of the lower Rimac delta sequence can be appreciated in Fig. 1 (photo taken from the ocean toward Cod. 28, Figs. 3 and 4), in which a cliff section in the Barranco district is shown.

Huamán (1991) carried out a thorough geotechnical study of La Punta and Callao. He compiled soil mechanical properties (density, thickness, SPT, shear wave velocities, lithology, standard classification of soil units, etc.) from boreholes and pits, as well as, making detailed microtremors surveys for estimating predominant frequencies of vibration of La Punta and Callao sites. These data have been fundamental in the application of the reported procedure to compute maximum seismic acceleration (PGA) from macroseismic intensity data. For the rest of Lima, soil information comes predominantly from Villanueva (1975) for Chorrillos district, and Polo (1977) for metropolitan Lima, among others. Locations of geotechnical borehole and pit data, as well as, the macroseismic intensity ratings observed during the 3 October 1974 earthquake are plotted in Fig. 3. 


\section{Results}

The results of the application of described procedure are shown in Fig. 4. The maximum accelerations at the boreholes and pits that are at or close to macroseismic intensity data were calculated. The computed values for Lima and Callao (excepting La Punta) range from 0.18 to $0.33 \mathrm{~g}$, A high value of $0.70 \mathrm{~g}$ was obtained at La Punta, where intensity rating of IGP and USGS reached a value of 9 MSK (MM) (Espinosa et al., 1977). Also, the maximum acceleration for IGP station and Las-Gardenias station reported by Moran et al. (1975), as well as, the maximum acceleration estimated near the sea cliff at Barranco by Espinosa et al. (1977) are plotted in this figure. The maximum accelerations at two boreholes near the IGP station are 0.25 and $0.27 \mathrm{~g}$, and the maximum acceleration observed at this station was $0.24 \mathrm{~g}$. The computed acceleration at the closest borehole to Las-Gardenias station is $0.19 \mathrm{~g}$, and the observed value was $0.18 \mathrm{~g}$.

On the other hand, Espinosa et al. (1977) estimated an amplification factor about 3 at the Barranco site where they estimated $0.7 \mathrm{~g}$ acceleration, in order to move and rotate a large size monument near the crown of the sea cliff. The closest computed acceleration, relatively far from the Barranco's cliff is $0.27 \mathrm{~g}$, upon the application of Espinosa et al.'s amplification factor, we obtain an acceleration of $0.8 \mathrm{~g}$, i.e., the estimated maximum acceleration at Barranco for the 3 October 1974 earthquake reasonably do agree (within 10\%).

\section{Conclusions}

The values of PGA estimated from macroseismic intensity data, site ground physical properties and predominant soil vibration frequency, using a computational method proposed here, are consistent with the observed data obtained during the 3 October 1974 Lima earthquake (8.1 Mw).

The macroseismic intensity data of the 3 October 1974 Lima earthquake were compared with the macroseismic effects, demonstrating that these data are useful for estimating maximum acceleration ground response in traditional districts of Lima City, Perú.

Acknowledgements. The procedure validation shown in this paper was possible thanks to the earthquake accelerations recorded at IGP station since 1954. I am grateful to P. Fabian, D. Keefer and an anonymous reviewer for their valuable comments and suggestions that led to improvement of the manuscript.

Edited by: P. Fabian

Reviewed by: D. Keefer and an anonymous referee

\section{References}

CISMID (Centro Peruano-Japonés de Investigaciones Sísmicas y Mitigación de Desastres): Estudio de vulnerabilidad y riesgo sísmico en 42 distritos de Lima y Callao: Ayuda Memoria, Universidad Nacional de Ingeniería. Facultad de Ingeniería Civil, Centro Peruano Japonés de Investigaciones Sísmicas y Mitigación de Desastres (CISMID), 2005.

Espinosa, A. F., Husid, H., Algermissen, S. T., and De Las Casas, J.: The Lima earthquake of October 3, 1974: Intensity distribution, Bull. Seism. Soc. Am., 67(5), 1429-1439, 1977.

Giesecke, A., Ocola, L., Silgado, E., Herrera, J., Giuliani, H.: El terremoto de Lima del 3 de Octubre de 1974, Informe Técnico preparado por CERESIS por encargo de UNESCO, 1980.

Huamán, C. E.: Microzonificación sísmica de La Punta y El Callao. Tesis para optar el Título Profesional de Ingeniero Civil, Universidad Nacional de Ingeniería, Facultad de Ingeniería Civil, Lima, Perú, 1991.

Husid, R., Espinosa, A. F., and De Las Casas, J.: The Lima earthquake of October 3, 1974: Damage distribution, Bull. Seism. Soc. Am., 67(5), 1441-1472, 1977.

Langer, C. and Spence, W.: The 1974 Perú earthquake series, Bull. Seism. Soc. Am., 85, 665-687, 1995.

Macazana, R. H.: Análisis dinámico de los acantilados de la Ciudad de Lima. Tesis para obtener el Grado de Maestro en Ciencias con Mención en Ingeniería Geotécnica, Universidad Nacional de Ingeniería: Facultad de Ingeniería Civil, Sección de Post-Grado, Lima, Perú, 2006.

Moran, D. F., Ferver, G., Thjiel Jr., Ch., Strata, J., Valera, J., and Wyllie Jr., L.: Engineering aspects of the Lima, Perú earthquake of October 3, 1974, The EERI Reconnaissance Team, Preliminary Reconnaissance Report (PDF), 1975.

Ocola, L.: La física de las escalas macrosísmicas y la actualización de catálogos macrosísmicos, Reunión de CERESIS: Actualización de catálogos de intensidades sísmicas. (Proyecto IPGH), Lima, Perú, November 23-24, 2005.

Pérez, M.: Características de los suelos de cimentaciones de Lima y Callao, Tesis para optar el título profesional de Ingeniero Civil, Universidad Nacional de Ingeniería, Programa Académico de Ingeniería Civil, Lima, Perú, 1976.

Polo, A.: Amplificación sísmica para Lima Metropolitana por efecto de las propiedades del suelo, Tesis para optar el título profesional de Ingeniero Civil, Universidad Nacional de Ingeniería, Programa Académico de Ingeniería Civil, Lima, Perú, 1977.

Telford, W. M., Geldart, L. P., Sheriff, R. E., and Keys, D. A.: Applied Geophysics, Cambridge University Press, Cambridge, London, 860 pp., 1976. 